\title{
Movement material
}

\section{A materialist approach to dance and choreography}

Rasmus Ölme*

The Danish National School of Performing Arts

\begin{abstract}
How can a materialist approach contribute to the development of contemporary dance and choreography? That is the question that this article aims to investigate through the formulation of the current status of the ongoing artistic research project Movement Material. The project relates to topics within the philosophy of materialism, but focuses on practical artistic research. The article delineates the knowledge production that may emerge from the exploration of a materialist approach to dancing, understood as an attunement between sensory and cognitive capacities. These two capacities are understood as relational and transposed into the practice through two terms, dance and choreography.
\end{abstract}

Keywords: Choreography; dance; artistic research; materialism; intra-action

\section{Sammanfattning}

Hur kan ett materialistiskt perspektiv bidra till utvecklingen av nutida dans och koreografi? Det är frågan som den här artikeln ställer genom att beskriva det pågående konstnärliga forskningsprojektet Movement Material. Projektet förhåller sig till den materialistiska traditionen inom filosofi men har sitt fokus i det praktiska konstnärliga undersökandet. Artikeln skisserar den kunskapsproduktion som kan komma ur det praktiska utforskandet av ett materialistiskt perspektiv på dans, som då förstås som en form av dialog mellan kroppens kognitiva och sinnliga förmågor. Dessa förmågor förstås som relationella i förhållande till varandra och översätts i det praktiska arbetet genom termerna dans och koreografi.

Nyckelord: Koreografi; dans; konstnärlig forskning; materialism; intra-aktion

Received: May, 2017; Accepted: October, 2017; Published: December, 2017

To contextualize the research topic in focus, the article starts by describing related research along with some background information about how my previous $\mathrm{PhD}$ research (From Model to Module - a Move Towards Generative Choreography (Ölme, 2014)) in the subsequent years, led to the formulation of the research questions of the current

^Correspondence: Rasmus Ölme, Den danske Scenekunstskole, Per Knutzonsvej 51437 København K, Denmark. Epost: raol@scenekunstskolen.dk 


\section{R. Ölme}

project Movement Material. ${ }^{1}$ I will specifically draw on two results from the $\mathrm{PhD}$ project that relate to what I call the materialisation of movement: 1 . body-self attunement and 2. kinaesthetic experience as tactile. I will then present a theoretical discussion of how a materialist approach to movement may be formulated, focusing on two texts, one from Gilles Deleuze and the other from Jane Bennett. To conclude this article, I will describe the investigative movement practice of the research project.

\section{Expanding from Within}

During the last decade, there has been a movement in European contemporary dance, referred to as the expanded notion of choreography. The term echoes Rosalind Krauss' 1979 essay Sculpture in the expanded field and testifies to a desire to detach choreography from its traditional connection to dance. ${ }^{2}$ For the 2012 conference "Expanded Choreography. Situations, Movements, Objects..." the term was referred to in the following way: ${ }^{3}$

In the last few years the term 'choreography' has been used in an ever-expanding sense, becoming synonymous with specific structures and strategies disconnected from subjectivist bodily expression, style and representation. Accordingly, the meaning of choreography has transformed from referring to a set of protocols or tools used in order to produce something predetermined, i.e. a dance, to an open cluster of tools that can be used in a generic capacity for both analysis and production.

Another, more recent, appearance of the term is from the title of the $\mathrm{PhD}$ publication of Danish choreographer Mette Ingvartssen (2016): EXPANDED CHOREOGRAPHY: Shifting the Agency of Movement in The Artificial Nature Project and 69 Positions. Ingvartssen does not explicate the origin of the term "expanded choreography", but describes her interest in distancing her work from the dancing human subject as "a reconsideration of how movements could be formed beyond the human body in its intersection with materials, machines, imaginations, affects and

\footnotetext{
${ }^{1}$ The $\mathrm{PhD}$ research took place in 2008- 2014 and was a collaboration between DOCH/Uniarts (School of Dance and Circus) and KTH (Royal Institute of Technology, School of Computer Science and Communication) in Stockholm, Sweden. The ongoing project Movement Material started in February 2017, ends in August 2018 and is financed by the Danish Ministry of Culture and The Danish National School of Performing Arts.

${ }^{2}$ Swedish choreographer Mårten Spångberg makes a claim of the term in an online interview: "After International Festival, I introduced a term we stole from Rosalind Krauss: choreography as expanded practice. This was all a matter of saying that choreography could be other than a dance. It's a mode of production." https://contemporaryperformance.com/2016/07/04/interview-marten-spangberg/ (accessed 07.11.2017)

${ }^{3}$ An event organized by the University College of Dance and Circus in Stockholm, the Museu d'Art Contemporani de Barcelona (MACBA), the Fundació Antoni Tàpies, and the Mercat de les Flors, with the support of the Swedish Research Council and the Swedish Arts Grants Committee, on the occasion of the exhibition Retrospective by Xavier Le Roy at the Fundació Antoni Tàpies. Devised by Mårten Spångberg. http://www.macba.cat/en/expanded-choreography-situations (accessed 07.11.2017)
} 
sensations" (Ingvartssen, 2016, p. 9). Ingvartssen sees this as "a way of proposing a non-anthropocentric notion of dance and the body, by including the expressions of non-human elements" (2016, p. 9). Expanded choreography refers to the usage of choreography outside of its more traditional relation to dance. This article, and the research project it refers to, shares the desire to broaden the horizon of what choreography may mean, but differs from the abovementioned desire to distance itself from dancing. My interests instead entail how an expansion can take place within choreography's relation to dance. Such an expansion "from within" is a questioning of choreography that does not look for an application outside of dance, or outside the body, but instead questions the supposedly evident relation between dance and choreography. I call this reconsideration of the two terms "dance AND choreography". Movement Material also proposes a different take on what could be understood as a non-human element. A materialist approach to the body can be seen as less anthropocentric, where it is the material body that choreographs the human subject just as much as vice versa.

\section{Generative Choreography}

The just mentioned "expansion from within" started with my PhD project by questioning the assumed dichotomy between choreography and improvisation. I found the common binary understanding of the two terms, and their mutual relation, too simplistic. It proposes an either/or logic that I could not relate to in practice. Looking at the contemporary use of structured improvisation, score making and movement investigation, I found that they do not represent freedom in the way that the common understanding of improvisation refers to. Nor do they fall under the common understanding of choreography as a set structure of movements in time and space. ${ }^{4}$ Instead, I experienced choreography and improvisation as two ends of one stick of possible negotiations between predetermination and contingency. To describe such negotiations, I proposed a modular concept as one example of a less binary relation between choreography and improvisation. The modular choreography proposes a flexible structure that contains a limited amount of input (modules) that can be reorganized (modulated) into a potentially infinite amount of outputs. To put such an assemblage in place I first need to identify its parts: the pieces that are going to form a whole. As several of the research presentations were site specific, I started by looking at the site through a choreographic perspective to see how that place/space was already choreographed. What choreographic elements were already at work in that space, and how did these elements (or modules) choreograph the work before it even got started?

\footnotetext{
${ }^{4}$ Examples of such scored improvisational practices are "event scores" by the Fluxus movement, American artist Bruce Nauman's scores, American choreographer Deborah Hay's koan-like "What if..."- questions and Suisse choreographer Thomas Hauert's improvisational work with his group Zoo Company.
} 


\section{R. Ölme}

The choreographic reading of the space could include a wide range of aspects, such as haptic, socio-economical, architectural or simply previous personal memories from that place. By looking at the choreography that was already at work, my own choreographic intervention became more about how to reorganize (modulate) what I found already active on site. To clarify, here is one concrete example:

MODUL 1 (2009) was presented in Färgfabriken; a large exposition hall in a former paint factory in the southern part of Stockholm. It was presented in the month of May when spring is arriving in the North, a period in which it is difficult to get people to give up on the lighter and milder outdoor season and go indoors to watch performing arts. As a consequence, we chose to make a 4-hour presentation that included a three-course meal, prepared in the hall by an invited chef. The doors were left open and people could come and go as they pleased. This mode of presentation also aligned with the profile of the exposition hall, as it allowed the visitors to walk in and out during the "opening hours" of the presentation. In addition, Färgfabriken already had a tradition of organizing this kind of mingling party that the format proposed. In that sense, the format of presentation was choreographed by the visiting mode of the venue and by the season in which we presented the work. ${ }^{5}$

I should emphasise that my choreographic perspective is by no means neutral. The context of a specific site is insatiable, and my experience of elements that have choreographic agency is already an expression of me, as perceiver. However, the recognition of the site's existing choreographic agency revealed a form of attunement between what I choreograph and what choreographs me, in other words: between moving and being moved. The two are distinct, yet inseparable. Although I am able to experience them differently and distinct from each other, I cannot clearly delineate their separation. This is what led to the use of the term generative in the subtitle of the thesis. Instead of thinking of choreography as a predetermined spatio-temporal structure, it became an activity that generates spatio-temporal structures. The relation between the choreography and the performed outcome is then no longer oneto-one, as the choreography is no longer the prescription to the followed outcome. Choreography does then not function as a mould that reproduces sameness but as a modular apparatus that generates differences. To acknowledge the elements that have choreographic agency and thus influence my movement, can be seen as a less authoritarian understanding of choreography. In that way, generative choreography shares an agenda with the expanded notion of choreography, as expressed in the 2012 "Expanded Choreography. Situations, Movements, Objects..." conference program, by not proposing a "set of protocols or tools used in order to produce something predetermined (...)". However, the continuation of the quote claims that this something predetermined is "i.e., dance". The expansion from within that I propose aims to de-polarize the two terms dance and choreography to instead explore the elasticity and resilience of their mutual relation.

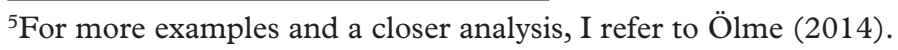




\section{Dance AND Choreography}

Karen Barad has proposed a form of relational thinking by coining the term intraaction that "signifies the mutual constitution of entangled agencies" (Barad, 2007, p. 33). The term differs from its related term "interaction" that presupposes the existence of determined and separate agencies that, once constituted, then interact with each other. Instead, Barad proposes intra-action that "recognizes that distinct agencies do not precede, but rather emerge through, their intra-action" (2007, p. 33). I want to propose this thinking mode as a way to understand dance AND choreography. Intra-action is also echoed in this text through my use of the term "attunement" that has already appeared three times so far: (a) the attunement between sensory and cognitive capacities; (b) the body-self attunement (further explained soon); (c) the attunement between how I move and what moves me. If intra-action refers to the formation of agencies, I see attunement as an unceasing engagement with that formation.

In the ongoing research project Movement Material, the effort to expand dance and choreography from within continues through the physical practice of dance AND choreography. One can dance without consciously engaging in choreography and one can choreograph without dancing, but I imagine that there is a specific area in which the two coincide. The practice of dance AND choreography speculates that there is a specific way of dancing that is choreographic, and vice versa: a specific way of choreographing that is dancy (for lack of a better word). The practice consciously engages in the attunement of moving and being moved, assuming that the dance choreographs the choreography as much as the choreography choreographs the dance. In this sense, dance AND choreography presents an expanded notion of dance, understood as an attunement between sensory and cognitive capacities. Cognition is a vast concept, and my use of it requires some delimitation. Here, cognitive capacities should be understood as the process of knowing related to the mind's faculty to plan and make conscious decisions. In terms of choreographic work, I understand this capacity in two ways: first, the conscious choice of a certain theme of the dance that could be practically anything, such as spatial relations, aesthetic preferences or political agendas. Second, I relate it to composition, as the more reflected choices made in relation to an overall structure. The sensory capacity refers to a less planned activity that feels its way through the direct kinaesthetic experience, as opposed to planning towards a specific goal, meaning or result.

There is an obvious parallel to the body-mind split here. The desire to expand dance is an effort to question the outdated, yet still prevailing, dominance of mind over matter. A dominance also reflected in the existing hierarchy within the ruling understanding of dance and choreography that presupposes the choreographer as the one with the original idea and the mental capacity to structure it into a coherent expression, while the dancer remains the mere medium - the doer who does not need to know what $\mathrm{s} / \mathrm{he}$ is doing. The concept of dance AND choreography aims at strengthening the position of dance and presents a subtler and less hierarchical 


\section{R. Ölme}

understanding of choreography than that of "the art of commanding", as it has been expressed by the American choreographer William Forsythe (Franko, 2007, p. 17). I do not see Forsythe as a representative of this view, although he expresses it well. Quite on the contrary, Forsythe has performed the sort of expansion from within that I advocate for and a testimony of this, expressed by himself, is how he considers "(...) choreography to be a secondary result of dancing" (Forsythe, 2003, p. 24).

\section{Movement Material}

For practitioners in the dance field, the term "movement material" signifies a movement phrase - a piece of choreography in its most traditional sense. But the term also reveals a set of questions on the ontological status of movement: Is there only matter that can be moved or can movement be seen as material? Is there movement in matter? Can one say that movement is or can movement only happen? Movement Material explores these questions to see how a materialist approach to movement may shift the conception of what it means to dance.

While teaching, I have repeatedly bumped into the limitation that the visual manifestation imposes on the definition of movement. Is movement really best understood from what it looks like? Surely, when describing a movement, words are used and there is other information than the visual involved in the communication, but the produced image usually remains the dominant factor in the construction of its meaning. I have found myself describing this problem using a similar vocabulary to the one I used above describing generative choreography: to shift the understanding of choreography from a predetermined spatio-temporal structure of an event to a set of parameters that are modulated to generate an event. Transposed to movement this means to look beyond the visual manifestation of a movement and ask what conditions I need to put in place to allow the movement to emerge. There is thus a subtle, yet radical, conceptual shift for a mover: instead of doing a movement, the mover needs to modulate the parameters of the material body to set up the favourable conditions for the movement to emerge. What is it that the mover needs to do to produce that specific movement? The question is not asked to have a more correct answer, like for example being able to name, preferably in Latin, exactly which anatomical parts perform what sort of action. The question is instead asked to reveal the enormous amount of micro actions that are at work inside even the simplest of movements. It calls for a closer relation to the kinaesthetic experience, so close that you can touch it. I call this approach movement materialisation, and I will now describe two practices that work with this concept.

\section{How to Materialize Movement: Body-Self Attunement and Kinaesthetic Experience as Tactile}

Dance, and the dancer as well, usually claims to be on the side of the body, but looking at the history of Western staged dancing (which is the tradition I see myself in) 
I find that dance has referred more to the symbolic body than the material. Whether it is a narrative, a perspective on human relations or an aesthetic ideal, a dance is understood as "about" something, an expression of something instead of an expression in itself. I do realize that I am generalizing and that this cannot be applied to the entire history of Western staged dance. Furthermore, I am far from alone in my desire to counter this tendency, and the two practices I will describe here should be seen as my contribution to that work of resistance. ${ }^{6}$ The intention of these practices is to make oneself sensitive to one's material existence, as a way to develop the sensory capacities that I refer to in the materialist approach of dance AND choreography.

\section{Example 1: Body- Self Attunement}

Fifteen years ago, I learnt a qi-gong exercise that I have since developed for my own purposes and turned it into something I call body-self attunement. Today I see this as the early formulation of how to materialize movement. At the time when I gave the practice its name, I saw the terms body and self as synonymous with the difference of the material and the symbolic body that founded the base of my just mentioned critique to the tradition I work in.

In the current research project, the different ways of expressing the material and immaterial ${ }^{7}$ are merged in the title Movement Material. It is the past 15 years of practising body-self attunement that has led to the formulation of dance AND choreography, as the attunement of cognitive and sensory capacities. Once again, the body/ self- binary points to the misconception of the body/mind-split, where the body is understood as the material and the self refers to our experience of being something more than body: the symbolic existence beyond the material, call it mind, spirit, identity or self. However, in spite of the persistent conceptual force of the body/ mind-split, we still intuitively situate our symbolic experience within the material body. Our symbolic existence as mental substance (res cogitans) remains within our material reach (res extensa). ${ }^{8}$ When saying "I" or "me", the person uttering the word

\footnotetext{
${ }^{6}$ The term practice has become an important one in the last $5-10$ years. The use of the term has a few different important aspects. It emphasises the doing, the practising, and underlines the importance of a continuous exercising of a certain activity. It is the doing that does. The term also relates to the post-internet ideology of sharing. In educational context, a practice is usually said to be shared, and thus presents itself as an alternative to terms like technique, task and exercise.

${ }^{7}$ In this text, I use the term "immaterial" instead of "symbolic", but in the PhD project (Ölme, 2014) I was referring to the dichotomy of material and symbolic as it has been articulated by French philosopher Catherine Malabou, in her course entitled "Plasticity of Life vs. Biopower". The course was given in 2012 at the European Graduate School in Saas-Fee, Switzerland. The course is published online at www.egs.edu. (accessed 07.11.2017)

${ }^{8}$ Res extensa and res cogitans were the two terms used by René Descartes to describe the duality between physical and the mental substances. (Descartes, René (1983) [1644,] Principia philosophiae (Principles of Philosophy). Translation with explanatory notes by Valentine Rodger and Reese P. Miller)
} 


\section{R. Ölme}

usually intuitively points to the chest. The body-self attunement addresses this paradox and I believe that the best way to explain how is to show: Body-Self Attunement. ${ }^{9}$

\section{Example 2: Kinaesthetic Experience as Tactile}

Previously in this article, I have described the kinaesthetic sensory capacity as a method to feel one's way through movement, getting close enough to the movement to touch it. This tactile relation to kinaesthetic experience is something I developed with the research group The Swarm (Svärmen) during the $\mathrm{PhD}$ project. ${ }^{10}$ It started as two separate practices called Inside Touch and Muscle Group, but in the current research project they have fused under the concept of kinaesthetic experience as tactile. When we touch something, the sensation takes place in our body, but we assign the quality of our sensation to the material we touch. I assign the stony quality to the stone, and not to my own sensation of the stone. Inside Touch proposes a flipped version of that logic, meaning that the surface that is touched is inside the body, but the sensation of it is in space. By letting the surface of our body (in adult age, we mostly use our hands) get in touch with the surface of an object, we will perceive a material quality of that object, and to find out more we usually keep moving, sliding the hand along it surface or moving the object in our hands. Inside Touch suggests that it is also such a tactile sensation that allows us to feel our own movements, but that what is touched is inside the body; tissues, sliding on each other, providing a kinaesthetic experience. To counter the internal dwelling sensation that comes with imagining the inside of the body (for example, closing the eyes and lowering the head), The Swarm worked with imagining that the experience takes place in the space and not in the body. To be more precise: as the body is in space and not separate from it, any bodily sensation can also be considered spatial.

The second practice - Muscle Group - focused on how a material quality experienced through touch could be transposed into a quality in movement. ${ }^{11}$ With the example of the stone, it would mean that I translate the "stone-iness" that I experience from touching the stone, into a "stony" movement vocabulary. In Muscle Group, we would start in a pile on the floor making sure to have a lot of contact surface with the other bodies. Before starting we would agree on a bodily material to focus on, such as skin, muscle, bone or fat. We would start by experiencing that quality by touching another body, but since someone would be touching you at the same time, the experience of quality would be both projected into another body and perceived in one's own body through the touch of the others. In relation to the flip side of tactile experience that we worked on with Inside Touch, Muscle Group revealed the obvious

\footnotetext{
${ }^{9}$ https://vimeo.com/242752813 (accessed 14.11.2017)

${ }^{10}$ Svärmen (The Swarm) worked on MODUL 6 and consisted of Linda Adami, Ulrika Berg, Dan Johansson, Tilman O'Donnell and Rasmus Ölme.

${ }^{11}$ This practice was inspired by an exercise I did in a workshop with Jan Burkhardt in 2011. Burkhardt is a Berlin based performer, teacher and researcher in the field of dance and choreography.
} 
fact that one cannot touch something without being touched by it, now in terms of quality, meaning that if I intentionally try to feel fat, my touch becomes "fatty". By choosing to focus on a certain physical quality, I experience that quality through my own touch and that of the others and simultaneously project that sensation back into the tissue of the other bodies. I understand this feedback loop in a similar way as the attunement described above between moving and being moved. Not only am I touched by what I touch, but also touched in the way I touch. In Muscle Group, we would move on to moving the other body with the quality we experienced through the touch, thus also moving one's own body with that quality. The last step was to lose the contact with the other bodies and to proceed on our own, maintaining the movement material that the tactile sensation had produced and thus having turned a material quality into an immaterial quality. In a way, we could understand this form of the materialization of movement from an opposite point of view - that of the immaterialization of matter.

\section{How to Immaterialize Matter}

Ten years ago, I participated in a class of Body-Mind Centering ${ }^{\circledR}\left(\mathrm{BMC} \mathrm{CM}^{\mathrm{SM}} \cdot{ }^{12} \mathrm{We}\right.$ were working on the vestibular system; we watched drawings of the cochlea and were informed about the different materials of which it consisted. Once we started to investigate through movement, I noticed how the movements I produced were mimicking the mental image that I had created of the cochlea. This resulted in a peculiar feeling of pretending to be my own body. The cochlea is a concrete piece of matter in my body, but not available to me through a direct experience. Although my body is a fundament in my existence, it remains obscure to me. The cochlea instead revealed itself through metaphors and representations: the drawings we had looked at and the verbal descriptions of its material qualities. Whenever I move, I move in relation to my vestibular system. It is not something I need to consciously engage. Therefore, when I decide to make my vestibular system the motivating force for my movement, I am moving as if the vestibular system decides my movement. Although the vestibular system is materially and factually at work in my movement, it is only available to me through a form of resemblance or likeness. In chapter 7, Perception in the Folds, in Gilles Deleuze's book The Fold, Leibniz and the Baroque (Deleuze, 1993/2006), Deleuze articulates an interesting argument on resemblance through the relation of what he calls micro and macro perceptions:

Macroperception is the product of differential relations that are established among micro- perceptions; it is thus an unconscious psychic mechanism that engenders the perceived in consciousness. (Deleuze, 1993/2006, p. 108)

\footnotetext{
${ }^{12} \mathrm{An}$ integrated and embodied approach to movement, the body and consciousness, developed by Bonnie Bainbridge Cohen. For more info see http://www.bodymindcentering.com/about (accessed 07.11.2017)
} 


\section{R. Ölme}

Deleuze then uses the example of the perceived pain of a needle penetrating the flesh, arguing that:

The perceived resembles something that it forces us to reflect upon [...] I feel a tremor of pain: this pain resembles the movement of something pointed that would dig into my flesh in concentric circles. (Deleuze, 1993/2006, p. 109)

The perception does not represent the needle, yet perception needs to make sense out of all the micro perceptions that the needle causes and sum them up into a macro perception that can be represented in the soul. ${ }^{13}$ This statement radically rearticulates the meaning of resemblance.

Resemblance is equated with what resembles, not with what is resembled. That the perceived resembles matter means that matter is necessarily produced in conformity with this relation, and not that this relation conforms to a pre-existing model. Or rather, it is the relation of resemblance, it is the likeness that is itself the model, that makes matter be that which it resembles. (Deleuze 1993/2006, p. 110)

Both the statement on the relation between micro and macro perceptions and the inverted logic of resemblance/resembled can shed some light on my experience of pretending to be my body in the example where I participated in the Body-Mind Centering ${ }^{\circledR}$ class. ${ }^{14}$ I needed to use the symbolic to reveal the material, which could be understood as a form of immaterialization of matter. In the aforementioned example of Muscle Group, the tactile experiment with physical qualities form a mental image - in Deleuze's (1993/2006, p. 108) words "engenders the perceived in consciousness" - of the material and enabled us to turn it into a movement vocabulary. A material was immaterialized and then re-materialized again through our material bodies.

There is one more example of the complex relation between material and immaterial that I would like to present, this time from theoretical research, and once again from Deleuze's The Fold, where a sentence caught my attention and revealed an entire field of enquiry. This time from the chapter The pleats of matter. In the Swedish translation, the short statement reads: "[...] materiens mekanism är fjädringen" (Deleuze, 2004, p. 38). When I turned to the English version, I found a very different translation than the one I would have done myself. It reads "[...] motivating force becomes the mechanism of matter." (Deleuze, 1993/2006, p. 7). Intrigued by the

\footnotetext{
${ }^{13}$ The reason I here use the term "soul", which is not a term I have opted for in the rest of the text, is motivated by the use of the term in the full quote: "In the first place, Leibniz is not stating that perception resembles an object, but that it evokes a vibration gathered by a receptive organ: pain does not represent the needle, nor its movement from one level to another, 'such as that of a wagon's wheel,' but the thousands of minute movements or throbs that irradiate in the flesh: 'It is true that pain does not resemble the movement of a pin; but it might thoroughly resemble the motions that the pain causes in our body, and might represent them in the soul" (Deleuze, 1993/2006, p. 109). ${ }^{14} \mathrm{An}$ interesting example of choreographic work that questions the relation between bodily fiction and reality is Emotional Anatomy developed by Stina Nyström, Sandra Lolax and Rosalind Goldberg http://1200m.org/stina/workshops-i-do/emotional-anatomy/ (accessed 07.11.2017)
} 
difference I looked at the French original: "[...] le mécanisme de la matière est le ressort" (Deleuze, 1988, p. 10). There is greater coherence between the Swedish and the French versions. Both use the verb "is", while the English version says "becomes" and the English version also flips the relation between the matter and the mechanism by saying that it is the motivating force that becomes the mechanism, instead of the saying that the mechanism of matter is the motivating force.

But what I am more interested in is the actual choice of word to translate the French ressort. The term appears several times in the same chapter and is consequently translated to "fjädring" in Swedish, while the English translation, for example, reads "a spirit in matter" (Deleuze, 1993/2006, p. 7) and "the motive force" (Deleuze, 1993/2006, p. 14). There is, in my opinion, no exact English translation of the Swedish word fjädring from the quote above. The first image that comes to my mind is the spring system of the suspensions of a car - the resilient mechanism that makes the hood sink down when you sit on it and then push back up as you get up. In French, ressort means both the actual spring and the mechanism of suspension. In Swedish, the term is not the same for the material and the mechanism, but related, as the actual spring is called fjäder (which also means feather). As an English translation, I will use here "springiness", but the use of the more abstract translations of "spirit in matter" and "motive force" opened up an important track in my research. I see the more abstract translations as an expression of what I describe as immaterialization. Just like the difference of stone/stone-iness in the Inside Touch and the needle/needle-iness from the Deleuze quote, the English translation maintains the abstraction as a way to give recognition to something immaterial in the matter. Upon reading "spring" the attention may turn to the object and not its mechanism. By using the more abstract terms of "motivating force" or "spirit in matter", the attention is instead pointed to a form of animate force within matter itself and thus suggests a form of movement in matter. The spring is not just an object that can move in a specific way; its movement is a part of what it is - its mechanism, its springiness. However, in the quote above, Deleuze is not speaking of a spring, but about any matter, claiming that the springiness (ressort/ fjädring) is the mechanism of any matter. But what does mechanism mean here?

In her book Vibrant matter - a political ecology of things, Jane Bennett (2010) dedicates chapter 5, Neither vitalism nor mechanism, to this question. Bennett is "looking for a materialism in which matter is figured as a vitality at work both inside and outside of selves, and is a force to be reckoned with without being purposive in any strong sense" (2010, p. 66). Bennett also notes how...

...the association of matter with passivity still haunts us today, I think, weakening our discernment of the force of things. But it might only be a small step from the creative agency of a vital force to a materiality conceived as itself this creative agent. (Bennett, 2010, p. 65)

In the chapter, Bennett draws on three different concepts: Hans Driesch's entelechy, Henri Bergson's élan vital and Immanuel Kant's Bildungstrieb. It is not the purpose 


\section{R. Ölme}

of this article to explain these concepts in detail, but I will briefly resume Bennett's interests in the first two of them to then proceed in my own ventures. Bennett draws on the three thinkers to question the idea of an immaterial force acting on matter, as the three concepts propose the presence of an immaterial force within matter. It is important to emphasize that this non-material force still only resides within matter. In the same way that I exemplified how the symbolic existence of a self still resides within the body, this immaterial force is not a spirit or psyche added to matter. Driesch proposes that entelechy resides in the gaps within matter or what he describes as the "only partial spatial portion" of nature (Bennett, 2010, p. 64).$^{15}$ This can be understood, at least on an intuitive level, how the space within matter allows for the mechanism of springiness, or resilience. Moving on, Bennett describes how Bergson's concept élan vital proposes matter as a "tendency towards spatialization" (Bennett, 2010, p. 77, original emphasis). ${ }^{16}$ I understand this tendency as an extension of the movement within matter, into space. Bennett quotes Driesch, explaining morphogenesis as "manifoldness in space is produced where no manifoldness was" (Bennett, 2010, p. 70). I thus imagine that movements are an extension into space of the pleats in matter that Deleuze used to entitle the studied chapter. The unfolding spatialization of morphogenesis continues through the capacity of our animate bodies to extend into space and produce maniFOLDness where before there was none. I have now, with the help of these thinkers, formulated two features of matter: springiness (ressort/fjädring) and the tendency towards spatialize.

\section{Suspension}

The different concepts presented thus far, both the philosophical concepts and the ones that emerged through practice, have merged into a physical practice that is the core of the practical research of Movement Material. To elaborate I will first return to my metaphor of the suspension of a car. Although I ended up with "springiness" as a possible translation to the French ressort, the English term suspension has been very important to me in physical practice, as it seems to reveal a crucial insight in terms of kinaesthetic experience. Next to the springiness, I have three associations to the term suspension: something hanging (sus-pended), a break in an activity (suspended from school) and the excitement felt in front of an unpredictable future (suspense). Using these three associations, I would describe the suspended body as defying gravity, free floating, awaiting and ready for a yet undefined event. The term "undefined" is

\footnotetext{
${ }^{15}$ Entelecheia was used by Aristotle to describe potential being actualized. Leibniz made use of the term in what he called "monads" that in his philosophy describes the thinking substance. See https:/www.britannica.com/topic/entelechy (accessed 07.11.2017). Driesch's use of it is briefly explained in this text.

${ }^{16}$ In the mentioned chapter, The Fold, Deleuze makes a similar note on this tendency of matter. Referring to Heinrich Wölfflin, Deleuze describes how "matter tends to spill over in space" (1993/2006, p.4).
} 
important here and should be understood as a suspension of definition that relates to the faculty of mind that I have described as cognitive. I cannot stop myself from knowing - and why would I want to !? - but I can suspend it. This leads to a negative definition of suspension. Instead of being an action in itself, the suspension is the suspension of another activity. However, suspending is not the same as stopping. Being suspended from school is not the same thing as being thrown out. It presupposes that there will be a re-integration. In the same sense, when I suspend a movement I do not stop moving. When a movement is suspended, the movement is still there, but not active. The force that generated the movement is still active, but it is balanced out through suspension, hovering in thin air.

The suspension thus shows a paradox within action. The activity is active, but not acting. Just above, I wrote "the movement is still there." Those words reveal a paradox: The double meaning of "still" suggests that there is no movement - it is still - but also that movement remains present - still there. If movement is always present, always still there, one could consider movement the default mode. Instead of thinking that there is first stillness and a movement needs to be activated, it is instead a question of releasing the suspension and allowing movement to move on. The movement does not need to be DONE, but instead the movement needs to be allowed to happen. This was the description I gave as an example, while making the connection between generative choreography and movement materialization: creating the conditions for a movement to appear rather than doing a movement. Just like my choreographic perspective was not neutral, the movements that come out of my body are not natural in the sense of free from culture or personal influences (nature/ culture is yet another dichotomy that Barad aims to undo through intra-action). In that sense, I am not blindly following some natural order. There is an active perceptual activity in feeling my way, in following the movement.

I can find similar articulations of suspension and movement as a default mode, in the already mentioned texts. Bennett explains how Driesch describes the immaterial force of entelechy in negative terms as it "relaxes its suspensory power" (2010, p. 72). The movement appears because suspension is relaxed. As for Deleuze, he describes how movement as a default mode can be detected as "cause for movement already present within the body, only awaiting the suppression of an obstacle from outside" (1993/2006, p. 14).

\section{Follow the Movement}

My claim is that the practicing of the materialization of movement can allow for the kinaesthetic experience as tactile. The attunement between symbolic and material existences shifts the perception of self. Relying on the resilient springiness of the material body, the suspensory power that suppress the obstacle relax and give space for matter's tendency towards spatialize. The pleats in matter spill over in space. Movement becomes an expression of the bodily material rather than of the human 


\section{R. Ölme}

subjects, as the "self" gets out of the way and allows the movement to pass through. Following the movement. But this following is not passive. It is the active and ongoing engagement in the attunement of sensory and cognitive capacities. As André Lepecki has put it:

However, dancing demonstrates before our eyes that there is much more to the work of the follower than to submissively shut up and walk behind in passive, or servile, or obedient participation." (Lepecki, 2013, p. 33)

Lepecki takes this as an example of what he calls "Followingleading" that he describes as "[...] leading by following, and of following by taking initiative [...]" (2013, p .34). He, in turn, refers to Canadian theorist Erin Manning, who has written on the subject of leading and following movement:

We walk. I am leading. But that does not mean I am deciding. Leading is more like initiating an opening, entering the gap, then following her response. How I follow, with what intensity we create the space, will influence how our bodies move together. I am not moving her, nor is she simply responding to me: we are beginning to move relationally, creating an interval that we move together. The more we connect to this becoming- movement, the more palpable the interval becomes. We begin to feel the relation. (Manning, 2009, p. 30)

Manning describes how one has to follow while leading when dancing with a partner. In my example, it is movement itself that is the partner and reveals how I have to lead while following. Again, this shows that the following is not a passive act. It is a hyper sensitive on-going attunement. Follow. Follow. Follow.

In his book The Animal That Therefore I Am (2008), French philosopher Jacques Derrida linguistically deconstructs the French translation of Renée Descartes Cogito Ergo Sum, commonly translated to English as "I think, therefore I am". The English translation does not lend itself to the pun that Derrida makes, as the French translation for "I am" is "je suis" and also means "I follow". The double meaning of "suis" could thus also propose the translation "The Animal That Therefore I Follow". The animal that I follow in the moving practice of the research project is my material body, and by doing so, I am. All of a sudden Brigitte Bardot's hit "Je pense donc je suis" (which with the double translation of "suis" means both "I dance therefore I am" and "I dance therefore I follow") shows more depth than at first glimpse.

\section{Conclusion}

Returning to the research question: What knowledge production can result from a materialist approach to movement, when moving is understood as attunement between sensory and cognitive capacities? I will seek to make some conclusions.

When it comes to the actual practicing of movement in the form of dance AND choreography the goal is to develop a specific movement expression. But next to the development of the art form, through the expansion from within, I believe that movement practice can contribute to the alternative understanding of thinking - that 
of intra-action. My repetitive use of the term "attunement" and the capital letters in "dance AND choreography" can serve as examples. I realize how I continuously set up dichotomies to collapse them: choreography/improvisation, symbolic/material, body/self. It is as if I need to create a tension between two points, like attaching a string, to play it. The playing happens between the suspending points and the attunement happens in the tonus between those points. But as "intra-action" proposes, it might instead be the playing that creates the attachment points. Manning describes the moving together of two dancing partners:

[...] provides a glimpse into the ways in which movement creates the potential for unthinking dichotomies that populate our worlds [...] It's not that movement directly undermines these dialectical concepts. It's that movement allows us to approach them from another perspective: a shifting one. (Manning, 2009, p. 14-15)

Staying in movement, following the movement and directing one's attention to its shifts may allow for such an undermining of dialectical concepts.

It is not until now, as I write these words, in November 2017, that the practical research in Movement Material really begins, and it will go on long after the publication of this article. It would therefore be premature to draw any conclusions of the work at this point. Similarly, I have not yet reached the point where I can be self-critical towards the method or the formulation of the score in its current form. To still offer a glimpse into the work, I will present the score that is the base of the practical research carried out by the Swarm during the coming months. First, the score:

30 min warm up - make sure your body becomes available to you, so you are ready to go when you start.

$30 \mathrm{~min}$ of dance AND choreography practice, materializing movement with the following ideas:

- Springiness (fjädring/ressort) as the basic mechanism.

- Matter's tendency to spatialize / to spill over in space.

- Follow the movement.

- $\quad$ Track your mind in the attunement of sensory and cognitive capacities.

45 minutes to write or record reflection and organize documentation (when practicing together this can be done together). I want you to include reflection on your experience of the relation between theory and practice. Post you documentation on the FB group page.

While preparing the score, I did a couple of pilot versions together with American choreographer Eleanor Bauer, who is currently a PhD candidate at Uniarts in Stockholm. I conclude this article with an excerpt from her documentation done during one of our sessions, emphasising that this is not a conclusion, but merely a start of an ongoing artistic research project focusing on the possible meanings of movement material and the relationship to dance AND choreography.

Follow the movement includes ideas for movement before they happen (cognition before sensation?). 


\title{
R. Ölme
}

Follow the movement includes whatever is already happening (cognition with sensation?).

Follow the movement includes being late with cognition (cognition after sensation?).

Follow the movement includes the movement of thought.

Follow the movement includes the movement outside of me.

Follow the movement includes the movement of virtual space.

Follow the movement brings sensation and cognition together.

\section{Author Bio}

After a career as dancer, Rasmus Ölme (ph.d.) formed his own group REFUG, producing his first work "This is not a Test" in 2001. In the following years, he produced and toured 5 productions, until 2008, as he started as a $\mathrm{PhD}$ candidate at $\mathrm{DOCH} / \mathrm{Uniarts}$ in Stockholm. Rasmus successfully defended his thesis "From Model to Module - a move towards generative choreography" in May, 2014 and was employed at DOCH/Uniarts as senior lecturer. Since January 2015 he is the leader of the Dance and Choreography education at The Danish National School of Performing Arts (DDSKS) in Copenhagen.

\section{Acknowledgements}

\author{
Linda Adami \\ Ulrika Berg \\ Eleanor Bauer \\ Dan Johansson \\ Tilman O'Donnell \\ Chrysa Parkinson \\ Ellen Söderhult
}

\section{References}

Barad, K. (2007). Meeting the Universe Halfway. Quantum Physics and the Entanglement of Matter and Meaning. Durham and London: Duke University Press.

Bennett, J. (2010). Vibrant matter: a political ecology of things. Durham: Duke University Press.

Deleuze, G. (1993/2006). The Fold: Leibniz and the Baroque. (Translation by Ton Conley). Minneapolis: University of Minnesota Press.

Deleuze, G. (2004). Vecket: Leibniz \& barocken. (Translation and foreword by Sven-Olov Wallenstein). Göteborg: Glänta.

Deleuze, G. (1988). Le pli: Leibniz et le Baroque. Paris: Minuit.

Derrida, J. (2008). The animal that therefore I am. New York: Fordham University Press.

Descartes, R. (1644/1983). The Principles of Philosophy. (Translation by V.R Miller and R.P. Miller). Boston: Reidel.

Forsythe, W. (2203). Improvisation Technologies: A Tool for the Analytical Dance. Karlsruhe, Germany: ZKM.

Franko, M. (2006). Dance and Politics, States of Exception. Dance Research fournal. Vol. 38, No. (1/2): (Summer - Winter, 2006), 3-18.

Ingvartssen, M. (2016). Expanded choreography: Shifting the agency of movement in The Artificial Nature Project and 69 positions. Lund: Lund University.

Lepecki, A. (2013). From Partaking to Initiating: Leadingfollowing as Dance's (a-personal) Political Singularity. In G. Siegmund and S. Hölscher (Eds.), Dance, politics E co-immunity (pp. 21-38). Zürich: Diaphanes.

Krauss, R. (1979) Sculpture in the Expanded Field. October, Vol. 8, (Spring 1979), 30-44. 
Manning, E. (2009). Relationscapes: movement, art, philosophy. Cambridge, Mass.: MIT Press.

Ölme, R. (2014). From model to module: a move towards generative choreography. (Diss.) Stockholm: Kungliga Tekniska högskolan.

\section{Digital references}

Interview Mårten Spångberg

https://contemporaryperformance.com/2016/07/04/interview-marten-spangberg/

(Accessed 07.11.2017)

Conference on expanded choreography

http://www.macba.cat/en/expanded-choreography-situations

(Accessed 07.11.2017)

European Graduate School, course by Catharine Malabou

www.egs.edu.

(Accessed 07.11.2017)

Body-Self Attunement,

https://vimeo.com/242752813

(Accessed 14.11.2017)

Body Mind Centering

http://www.bodymindcentering.com/about

(Accessed 07.11.2017)

Emotional Anatomy

http://1200m.org/stina/workshops-i-do/emotional-anatomy/

(Accessed 07.11.2017)

Entelechy

https://www.britannica.com/topic/entelechy

(Accessed 07.11.2017)

\section{Choreographers and companies referred to}

William Forsythe (https://en.wikipedia.org/wiki/William_Forsythe_(choreographer))

Rosalind Goldberg

Mette Ingvartssen (http://www.metteingvartsen.net/)

Sandra Lolax

Stina Nyberg (http://1200m.org/stina/)

Mårten Spångberg (http://martenspangberg.se/)

Xavier Le Roy (http://www.xavierleroy.com/)

Jan Burkhardt

Bruce Nauman (https://en.wikipedia.org/wiki/Bruce_Nauman)

Deborah Hay (http://www.deborahhay.com/)

Thomas Hauert and Zoo Company (http://www.zoo-thomashauert.be/) 